\title{
Molecular analysis of urban rabies case from vampire bat in Corrientes, Argentina
}

\author{
Miranda, A.O. '; Núñez, S.E. ${ }^{1}$; Martinez, L. ${ }^{3}$; Gury-Dohmen, F.R. ${ }^{2}$; Cisterna, D.M. ${ }^{3}$ \\ ${ }^{1}$ Laboratorio de Investigaciones y Diagnóstico de Rabia, Facultad de Ciencias Veterinarias, UNNE, \\ Sargento Cabral 2139, Corrientes 3400, Argentina, Tel/Fax 03783-425753. ${ }^{2}$ Instituto de Zoonosis \\ "Dr. Luis Pasteur", Diaz Velez 4821, Buenos Aires 1406. ${ }^{3}$ Servicio de Neurovirosis INEI-ANLIS \\ "Dr. Carlos G. Malbran”, Av. Velez Sarsfield 563, Buenos Aires (1281), Tel/Fax 114302-5064. \\ E-mail: inmuno@vet.unne.edu.ar
}

\begin{abstract}
Miranda, A.O.; Núñez, S.E.; Martinez, L.; Gury-Dohmen, F.R.; Cisterna, D.M.: Molecular analysis of an urban rabies case caused by a vampire bat in Corrientes, Argentina. Rev. vet. 20: 2, 77-80, 2009. In April 2006, rabies virus (RABV) was detected in a domestic cat from Corrientes City, Argentina. Molecular characterization identified Desmodus rotundus as the reservoir species. Genetic analyses of $22 \mathrm{RABV}$ strains obtained from D. rotundus between 1988 and 2006 in Argentina, revealed the co-circulation of two genetic lineages in Corrientes Province. Alteration of the ecosystem of vampire bats by human intervention in this region could explain such changes in their behavior, as well as rabies virus circulation.
\end{abstract}

Key words: cat, vampire bat, rabies, molecular epidemiology.

\begin{abstract}
Resumen
Miranda, A.O.; Núñez, S.E.; Martinez, L.; Gury-Dohmen, F.R.; Cisterna, D.M.: Análisis molecular de un caso de rabia urbana causado por un murciélago vampiro en Corrientes, Argentina. Rev. vet. 20: 2, 77-80, 2009. En abril de 2006 se detectó virus de la rabia (RABV) en un gato doméstico de la ciudad de Corrientes, Argentina. La caracterización molecular identificó al murciélago Desmodus rotundus como la fuente viral. El análisis genético de 22 cepas de RABV aisladas de D. rotundus obtenidos entre 1998-2006 en Argentina, reveló la cocirculación de dos linajes genéticos en la Provincia de Corrientes. La alteración por parte del hombre, del ecosistema del murciélago en la región, podría explicar los cambios en su comportamiento y en la circulación del virus de la rabia.
\end{abstract}

Palabras clave: gato, vampiro, rabia, epidemiología molecular.

\section{INTRODUCTION}

The last case of terrestrial rabies transmitted by dogs or cats in Corrientes Province was in the late $80 \mathrm{~s}$. At this time, viral activity is related to rabies transmitted by more common vampire bat, Desmodus rotundus. Two cases of human rabies associated with that species have occurred in Isla del Cerrito, Chaco Province (1997), and San Luis del Palmar, Corrientes Province $(2001)^{8}$.

D. rotundus is a non-migratory colonial species that roosts in natural shelters or in places associated with human beings. They may use several refuges and can share them with other bat species. Their home range was described between 10 and $20 \mathrm{~km}^{2}$. As vampire bats feed on mammalian blood, the distribution of bat populations is affected by food availability, specially livestock ${ }^{4,9}$.

Recibido: 6 agosto 2009 / Aceptado: 15 setiembre 2009
In April 2006, a domestic cat from the suburbs of Corrientes City, with no history of rabies vaccination, showed a strange and aggressive behavior. It attacked two human beings and several dogs and cats. Two days later it died. After that, postmortem brain tissue samples were obtained and tested positive for rabies virus (RABV). Molecular research identified to D. rotundus as the species reservoir and revealed the circulation of a previously not recognized rabies lineage in that region ${ }^{2}$.

The aim of this study was to analyze the molecular characteristics of an urban rabies case associated a $D$. rotundus bat occurred in Corrientes city in 2006 .

\section{MATERIAL AND METHODS}

Virus isolates and sequences. A rabies isolate obtained from a cat from Corrientes City, and others five samples collected few months later within a radius of $10-20 \mathrm{~km}^{2}$ from the place where the cat was detected, 
Table 1. Rabies isolates from Argentina analyzed in this study

\begin{tabular}{|c|c|c|c|c|}
\hline isolates & city, province & source & year & $\begin{array}{l}\text { genetic } \\
\text { variant }\end{array}$ \\
\hline $\mathrm{C} 0 \mathrm{Ct}-\mathrm{Cte} 06$ & Corrientes City, Corrientes & cat & 2006 & DR2 \\
\hline $\mathrm{C} 1 \mathrm{Bv}-\mathrm{Cte} 06$ & Paso de la Patria, Corrientes & bovine & 2006 & DR1 \\
\hline $\mathrm{C} 2 \mathrm{BvCha06}$ & Isla del Cerrito, Chaco & bovine & 2006 & DR1 \\
\hline $\mathrm{C} 3 \mathrm{Bv}-\mathrm{Cte} 06$ & Isla del Cerrito, Chaco & bovine & 2006 & DR1 \\
\hline $\mathrm{C} 4 \mathrm{Hr}-\mathrm{Cte} 06$ & Km 1023, Corrientes & horse & 2006 & DR2 \\
\hline $\mathrm{C} 5 \mathrm{Bv}-\mathrm{Cte} 06$ & Empedrado, Corrientes & bovine & 2006 & DR1 \\
\hline CteBv5-03 & General Paz, Corrientes & bovine & 2003 & DR1 \\
\hline $655 \mathrm{bv}-\mathrm{Sal} 03$ & Unknown, Salta & bovine & 2003 & DR2 \\
\hline Chabv129-02 & Gral San Martín, Chaco & bovine & 2002 & DR1 \\
\hline Ctehm82-01 & San Luis del Palmar, Corrientes & human & 2001 & DR1 \\
\hline Chahr90-01 & Colonia Mixta, Chaco & horse & 2001 & DR1 \\
\hline Chabv86-01 & La Leonesa, Chaco & bovine & 2001 & DR1 \\
\hline Ctebv79-00 & San Miguel, Corrientes & bovine & 2000 & DR1 \\
\hline Ctebv55-00 & Colonia Romero, Corrientes & bovine & 2000 & DR1 \\
\hline Ctebv77-00 & Concepción, Corrientes & bovine & 2000 & DR1 \\
\hline Chabv74-00 & Colonia Mixta, Chaco & bovine & 2000 & DR1 \\
\hline Chabv72-00 & Puerto Veloz, Chaco & bovine & 2000 & DR1 \\
\hline Chabv78-00 & Colonia Mixta, Chaco & bovine & 2000 & DR1 \\
\hline Chabv66-00 & San Martin, Chaco & bovine & 2000 & DR1 \\
\hline Ctebv01-99 & Beron de Estrada, Corrientes & bovine & 1999 & DR1 \\
\hline $5578 b v-S a 198$ & Unknown, Salta & bovine & 1998 & DR2 \\
\hline 4379bv-Juy98 & Unknown, Jujuy & bovine & 1998 & DR2 \\
\hline Batbbt123 & 3 de febrero, Buenos Aires & Tadarida brasiliensis bat & 2001 & $\mathrm{~TB}$ \\
\hline Sfemnbt116 & Rosario, Santa Fe & Myotis nigricans bat & 2001 & MY \\
\hline StcHmbat 80 & Rio Turbio, Santa Cruz & Histiotus montanus bat & 2000 & HM \\
\hline Lc597-BA00 & Villa Ballester, Buenos Aires & Lasiurus cinereus bat & 2000 & LA \\
\hline Saldg04 & Oran, Salta & $\operatorname{dog}$ & 2002 & TR1 \\
\hline Saldg146 & Oran, Salta & $\operatorname{dog}$ & 2002 & TR1 \\
\hline Chadg120 & Pampa Almiron,Chaco & $\operatorname{dog}$ & 2001 & TR2 \\
\hline Chafx119 & Laguna Limpia, Chaco & fox & 1999 & TR2 \\
\hline
\end{tabular}

were analyzed. Others 16 historical rabies sequences from vampire related-cases of Corrientes, Chaco, Jujuy and Salta provinces and eight nucleotide sequences from insectivorous and terrestrial species, were included in this study for comparison purposes only (Table 1).

$R T-P C R$ and DNA sequencing. Viral RNA was extracted from samples using TRIzol ${ }^{\circledR}$ (Invitrogen, Carlsbad, CA, USA), following the manufacturer's instructions. Reverse transcription and PCR amplification were achieved with primers $10 \mathrm{~g}$ and 304 , as previously described ${ }^{14}$. The amplified product was sequenced using the Taq Big Dye Terminator Cycle Sequencing Ready Reaction Kit, according to the manufacturer's protocol on an Applied Biosystems 377 DNA automated sequencer (Applied Biosystems Inc. Foster City, California, USA).

Phylogenetic analysis. A 264-bp region corresponding to the nucleoprotein gene located between nucleotides 1157 and 1420 and amino acids 363 to 450, according to positions for the fixed laboratory strain SAD B19, was analyzed. Complete alignment was performed with Clustal X 1.8 software ${ }^{16}$. Matrix data was analyzed using Kimura 2 parameters as a method of nucleotide substitution and Neighbor-Joining to reconstruct the phylogenetic tree (MEGA version 4.1) ${ }^{15}$. The statistical significance of the phylogenies constructed was estimated by bootstrap analysis with 1000 pseudoreplicate data sets. Bootstrap values above $60 \%$ were considered significant.

\section{RESULTS}

A total of 22 rabies sequences obtained from vampire-related cases segregated into a group identified as DR, well supported by high bootstrap values as shown in Figure 1. The remaining Argentinean samples, represented by others rabies reservoirs, grouped into different genetic groups: TB (Tadarida brasiliensis), MY (Myotis sp.), HM (Histiotus montanus), LA (Lasiurus cinereus), TR1 and TR2 (Terrestrial 1 and 2) showing 
a genetic distance between 14.3 and $18.8 \%$ with $D$. rotundus group.

Group DR was divided into two lineages (DR1 and DR2) showing an average nucleotide and aminoacid distance between them of $1.9 \%$ and $0.0 \%$, respectively. Lineage DR1 included 13 historical samples obtained between 1999 and 2003 from Chaco and Corrientes provinces together with four samples $(\mathrm{Clbv}-\mathrm{Cte} 06$, C2bv-Cte06, C3bv-Cte06, and C5bv-Cte06) collected from different sites near Corrientes City in 2006. This lineage was further separated into two sublineages geographically related: DR1a, that contained samples from Corrientes and DR $1 \mathrm{~b}$ which grouped isolates from Chaco. Lineage DR2 included five samples: a cat (C0ctCte06) from Corrientes City and a horse obtained at KM1023, both recovered in 2006 and three historical samples from Salta (1998 and 2003) and Jujuy (1998). Geographic location of genetic variants circulating in Corrientes Province is shown in Figure 2.

\section{DISCUSSION}

Presence of the vampire bat in urban region is unusual. In the past five years, two episodes have been reported in Brazilian cities, one associated with dogs attacks ${ }^{3}$ and other with a bat specimen infected with RABV ${ }^{5}$. Several ecological factors can explain the presence of vampire bats in the area of Corrientes City: (i) abundant livestock a few kilometers of the city, (ii) large numbers of domestic animals (potential victims of the bat), and (iii) high availability of artificial shelters ${ }^{1}$. In addition, in front of the city, few kilometers on north, place Isla del Cerrito (Chaco Province) where have been reported frequent activity of vampire bats and human beings attacks ${ }^{10}$.

In Corrientes Province, after extend paralytic rabies epizootic outbreaks from 1997 to 2003, only sporadic cases were identified ${ }^{11}$. However, just few months after the detection of feline case, new cases of paralytic rabies were reported on Isla del Cerrito and others surrounded to Corrientes City. Reasons of the reemergence of rabies in this area are difficult to establish but human interventions in bats ecosystem are usually reflected in changes in its pattern of transmission.

On March 2006, the National Service of Animal Health and Food Quality (SENASA) sacrificed over 4,000 bovines in San Luis del Palmar, $15 \mathrm{~km}$ distant from Corrientes City, due to an outbreak of foot-andmouth disease ${ }^{13}$. This serious disruption of bat habits could have caused the displacement of bat colonies, from locations that did not contain enough cattle to sustain the populations of vampire bats, to bordering areas of Corrientes City in search to improve the availability of others source of food such as domestic animals. However, we cannot exclude additional unknown causes and other investigations should be conducted to answer this question.

Vampire bat-related rabies viruses have been genetically typed as being a species-specific variant ${ }^{6}$. Genetic diversity among different variants is attributed to aspects of the ecology of the vampire and topography of the habitat in which geographic features can act as natural barriers and cause the movement of regionally differentiated lineages ${ }^{7}$. The study of isolates from Corrientes in 2006 revealed the co-circulation of two lineages in this area. One predominant (DR1) associated with the epizooty occurred between 1997 and 2003 and another minority (DR2) associated with cases occurred in Salta and Jujuy (1998-2003).

The presence of both lineages in Corrientes could be explained by the fact that the minority lineage was possibly maintained by small populations of vampires in a re-
Figure 1. Philogenetic tree of vampire bat-related rabies viruses from Argentina (1998-2006). 
stricted geographic area. Its resurgence could be other consequence of the movement of bats occurred as a result of cattle lost by footand-mouth disease outbreak in San Luis del Palmar as was mentioned above. A phylogeographic study involving a large collection of rabies strains associated with $D$. rotundus from all provinces during an extended period of time would help to understand the historical circulation of rabies in vampire bats in Argentina.

Recently, Pan American Health Organization (PAHO), pointed out that the number of human cases of rabies transmitted by vampire bats is bigger than those of transmitted by dogs ${ }^{12}$. Our findings underscores the importance of de-

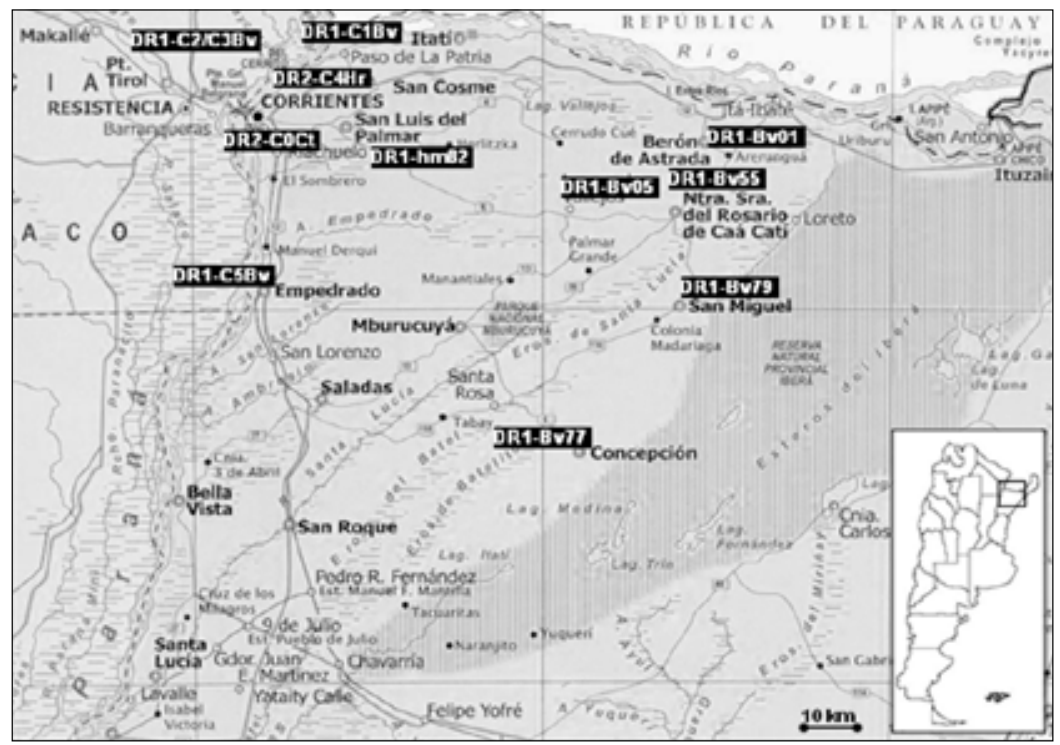

Figure 2. Geographic distribution of rabies genetic variants obtained from vampire related cases from Corrientes Province (1999-2006).

tection of unusual cases of rabies associated with vampire cases that represents a warning signs and should remind us that the human risk of rabies transmission from vampire bats is always present and should not be undervalued.

\section{REFERENCES}

1. Anonymous. 2008. Detectan en Corrientes mayor presencia de murciélagos transmisores de rabia paresiante. On line: http://revistacyt.unne.edu.ar/veterinaria19.html.

2. Cisterna D, Bonaventura R, Caillou S, Pozo O, Andreau ML, Fontana LD. 2005. Antigenic and molecular characterization of rabies virus in Argentina. Virus Res 109: 139-147.

3. Dantas Torres F, Valenca C, Andrade Filho GV. 2005. First record of Desmodus rotundus in urban area from the city of Olinda, Pernambuco, Northeastern Brazil: a case report. Rev Inst Med Trop Sao Paulo 47: 107-108.

4. Delpietro HA, Russo RG. 1996. Ecological and epidemiologic aspects of the attacks by vampire bats and paralytic rabies in Argentina and analysis of the proposals carried out for their control. Rev Sci Tech 15: 971-984.

5. Ferraz C, Achkar SM, Kotait I. 2007. First report of rabies in vampire bats (Desmodus rotundus) in an urban area, Ubatuba, Sao Paulo state, Brazil. Rev Inst Med Trop Sao Paulo 49: 389-390.

6. Kobayashi Y, Ogawa A, Sato G, Sato T, Itou T, Samara SI. 2006. Geographical distribution of vampire bat-related cattle rabies in Brazil. J Vet Med Sci 68: 1097-1100.

7. Kobayashi Y, Sato G, Mochizuki N, Hirano S, Itou T, Carvalho AA. 2008. Molecular and geographic analyses of vampire bat-transmitted cattle rabies in central Brazil. BMC Vet Res 4: 44.

8. Larghi OP, Delpietro H. 2004. Casos de rabia humana transmitida por murcielagos, Argentina. En: Temas de
Zoonosis (Cacchione RA, Durlach R, Larghi OP, ed), Publ. Asociacion Argentina de Zoonosis, Buenos Aires, p. 135138.

9. Lord RD, Fuenzalida E, Delpietro H, Larghi OP, de Diaz AM, Lazaro L. 1975. Observations on the epizootiology of vampire bat rabies. Bull Pan Am Health Organ 9: 189-195.

10. Miranda AO, Acosta R, Marder G, Jacobo R, Báez N. 2003. Persistente epidemia de rabia bovina (paresiante) en la Provincia de Corrientes (Argentina), período 19972003. Comunicaciones Cientificas y Tecnológicas 2003, Universidad Nacional del Nordeste (Argentina). On line: http://www.unne.edu.ar/cyt2003/cyt.html.

11. Miranda AO, Acosta R, Laffont HM, Báez N, Marder G, Jacobo R. 2005. Confirmación del virus rábico transmitido por murciélagos en bovinos del nordeste argentino mediante seroneutralización en ratón. Rev Vet 16: 36-39.

12. Schneider MC, Romijn PC, Uieda W, Tamayo H, da Silva DF, Belotto A. 2009. Rabies transmitted by vampire bats to humans: an emerging zoonotic disease in Latin America? Rev Panam Salud Publ 25: 260-269.

13. SENASA. 2006. Resolución 35/2006. On line: http://www. senasa.gov.ar.

14. Smith JS. 1995. Rabies virus. In: Manual of clinical microbiology (Murray PR, Pfaller MA, Tenover FC, Yolken R, ed.), American Society for Microbiology Press, Washington, p. 997-1003.

15. Tamura K, Dudley J, Nei M, Kumar S. 2007. MEGA4: Molecular Evolutionary Genetics Analysis (MEGA) software version 4.0. Mol Biol Evol 24: 1596-1599.

16. Thompson JD, Higgins DG, Gibson TJ. Clustal W. 1994. Improving the sensitivity of progressive multiple sequence alignment through sequence weighting, position-specific gap penalties, and weight matrix choice. Nucleic Acids Res 22: 4673-4680. 